\title{
The Spatial Spillover Effect of Financial Agglomeration on China's Regional Economic Growth
}

\author{
Maoguo $\mathrm{Wu}^{1} \& \mathrm{Nan} \mathrm{Gu}^{1}$ \\ ${ }^{1}$ SHU-UTS SILC Business School, Shanghai University, China \\ Correspondence: Maoguo Wu, SHU-UTS SILC Business School, Shanghai University, China. E-mail: \\ wumaoguo@shu.edu.cn
}

Received: April 29, 2019

Accepted: May 28, 2019

Online Published: June 6, 2019

doi:10.5539/ijef.v11n7p61

URL: https://doi.org/10.5539/ijef.v11n7p61

\begin{abstract}
With the development of economic globalization and economic integration, the regional capital flow accelerated, the flow of resources to expand the scope of the financial industry agglomeration effect is most obvious, leading to form a financial center in some areas highly concentrated. The paper analyzes the agglomeration of China's current banking industry, securities industry and the insurance industry three big financial pillar industries, through the establishment of comprehensive evaluation index system of financial agglomeration, of China's provinces (municipalities and autonomous regions) of the financial agglomeration level determination. The relevant panel data collected from 2006-2015 in 31 provinces in China, combined with the geographical position, building spatial econometric model, to study China's financial agglomeration on the spatial spillover effect of economic growth. The empirical results show that the provincial financial agglomeration has a significant impact on the economy and the surrounding provinces, and has a significant spatial spillover effect. At the same time, the financial agglomeration has different characteristics on the economic development of the eastern, central and western regions. The paper puts forward some policy suggestions on the development of the financial industry under the new situation of the supply side reform in different regions.
\end{abstract}

Keywords: financial agglomeration, regional economic growth, spatial panel data model

\section{Introduction}

With the development of economic globalization and economic integration, the speed and scope of financial capital have been improved and expanded. The three economic circles represented by the Yangtze River Delta, the Pearl River Delta and the Bohai Sea are representatives of China's financial industry. Shanghai, Shenzhen and Beijing have gathered most of the financial resources in the financial cluster. Although China's financial agglomeration center is relatively mature, it still has a significant gap compared with the international financial center. On the other hand, due to China's special national conditions, the development of the eastern and western regions is extremely uneven. The three major financial agglomeration regions are located on the eastern coast, and the development of the central and western regions is even more backward. Therefore, the impact of financial agglomeration on supply-side reform on regional economic development, and how to optimize financial agglomeration under supply-side reform has become the subject of discussion under supply-side reform.

\section{Related Literature}

In recent years, there have been many studies on financial agglomeration, regional growth and spatial spillover effects. Bai et al. (2012) analyzed the spatial structure and spatial spillover effect of economic growth in China's provinces from 1998 to 2008, and believed that the development of labor, capital, labor and market promoted regional development. Li et al. (2014) used the Spatial Durbin Model of improved weight to test the financial agglomeration and its relationship to urban economic growth based on panel data from 1995 to 2011 in China. It has also gathered a variety of resources brought about by financial agglomeration, and there is a space spillover effect. Zhou et al. (2014) calculated the location entropy index of banking, securities and insurance industries in the five provinces in northwest China and analyzed the agglomeration level of financial industry, finding that the lack of scale strength of Shaanxi's financial industry has a low contribution to the economy. Wang Yu et al. (2015) constructed a dynamic stochastic general equilibrium model of financial agglomeration, and studied the internal relationship between international financial center construction and financial agglomeration from the 
perspective of news shock, finding that the message itself would have an impact on the scale and speed of financial agglomeration. Li et al. (2016), Sun et al. (2017) also conducted related research. Through the collation of existing literature and the combination of theoretical analysis and panel data measurement, they found that the time span was small, and there are different opinions on the selection of indicators for the degree of financial agglomeration in terms of data selection. Therefore, it was necessary to conduct research on the domestic provinces and the eastern, central and western regions respectively, and compared the spatial spillover effects of China's financial agglomeration on the economic growth of various provinces in China after combining the spatial characteristics.

\section{Data and Empirical Analysis}

A total of 10 years of data from 31 provinces, municipalities and autonomous regions in China were constructed to build panel data from 2006 to 2015. In order to maintain a high degree of data consistency, the raw data is taken from the National Bureau of Statistics, the China Statistical Yearbook and the China Financial Statistical Yearbook, with the exception of individual data. Variables description is summarized in Table 1 below.

Table 1. Measurement system for financial industry agglomeration

\begin{tabular}{|c|c|c|}
\hline Variable classification & Variable definitions & Variable interpretation \\
\hline Explained Variable & Real GDP per capita (GDP) & Real GDP / Population \\
\hline \multirow{5}{*}{$\begin{array}{l}\text { Explanatory } \\
\text { Variables }\end{array}$} & Scale of Financial Resources (RES) & $\begin{array}{l}\text { The added value of the financial industry accounts for the } \\
\text { proportion of the added value of the national financial industry }\end{array}$ \\
\hline & Scale of Financial Practitioners (PAR) & $\begin{array}{l}\text { The proportion of employed persons in urban units in the } \\
\text { financial industry to the employment of urban units in the } \\
\text { financial industry }\end{array}$ \\
\hline & Banking Location Entropy (BAN) & Location entropy of institutional year-end deposit balance \\
\hline & Securities industry location entropy (SEC) & Location entropy of total stock market value \\
\hline & Insurance industry location entropy (INS) & Location entropy of premium income \\
\hline \multirow[t]{12}{*}{ Control Variables } & $\begin{array}{l}\text { Per Capita Social Investment In Fixed } \\
\text { Assets (INV) }\end{array}$ & $\begin{array}{l}\text { The total amount of real fixed assets investment after the gradual } \\
\text { decrease in } 2006 \text { / Population }\end{array}$ \\
\hline & Average Educational Level (EDU) & $\begin{array}{l}\text { Multiply the proportion of the number of students in primary } \\
\text { schools, junior high schools, high schools, and higher education } \\
\text { in each province to the number of permanent residents at the end } \\
\text { of the year by } 6,9,12 \text {, and } 16 \text { and sum them. }\end{array}$ \\
\hline & Per Capita Export (EXP) & $\begin{array}{l}\text { The actual export value of enterprises with import and export } \\
\text { management rights registered at the local customs / Year-end } \\
\text { resident population of each province }\end{array}$ \\
\hline & Urbanization Rate (URB) & Urban population / Resident population at the end of the year \\
\hline & \multirow{2}{*}{ Localized Economy (LOE) } & Provincial industrial added value/Provincial GDP \\
\hline & & National industrial added value $/$ National GDP \\
\hline & \multirow[b]{2}{*}{ Porter Externalities (POE) } & $\begin{array}{c}\text { Number of industrial enterprises } \\
\text { above designated size }\end{array} / \begin{array}{c}\text { Provincial industrial } \\
\text { added value }\end{array}$ \\
\hline & & $\begin{array}{c}\text { Number of } \\
\text { companies nationwide } / \text { National industrial } \\
\text { added value }\end{array}$ \\
\hline & Economic Basis (ECB) & General budgetary expenditures of local finance \\
\hline & Technology Level (S\&T) & Authorized amount of domestic patent application \\
\hline & Infrastructure Construction Level (LIC) & Local government transportation expenditure \\
\hline & Unemployment Rate (UER) & Urban registered unemployment rate \\
\hline
\end{tabular}

Moran's I test was used to verify the spatial correlation of the interpreted variables. Firstly, the spatial matrix Wij was constructed by using the latitude and longitude of the centers of 31 provinces, municipalities and autonomous regions in China, and the average value, standard deviation, maximum value and minimum value were calculated. The Euclidean distance of each interval was calculated by the formula, and the spatial 
correlation test was performed on the explained variables in each year. The results of the Moran's I test for the relevant variables for each province from 2006 to 2015 are shown in Table 2.

Table 2. Moran's I test results of per capita GDP in each province

\begin{tabular}{cccc}
\hline Year & Moran's I value & Year & Moran's I value \\
\hline \multirow{2}{*}{2006} & $0.16^{* * *}$ & 2011 & $0.18^{* * *}$ \\
& $(5.359)$ & & $(5.706)$ \\
2007 & $0.162^{* * *}$ & 2012 & $0.178^{* * *}$ \\
& $(5.361)$ & & $(5.642)$ \\
2008 & $0.172^{* * *}$ & 2013 & $0.175^{* * *}$ \\
& $(5.588)$ & & $(5.575)$ \\
2009 & $0.176^{* * *}$ & 2014 & $0.168^{* * *}$ \\
& $(5.657)$ & & $(5.377)$ \\
2010 & $0.181^{* * *}$ & 2015 & $0.164^{* * *}$ \\
& $(5.764)$ & & $(5.262)$ \\
\hline
\end{tabular}

From 2006 to 2015, the per capita GDP of each province passed the significance test at the $1 \%$ significance level. The data in parentheses indicates the $\mathrm{z}$ statistic of each group's data. From the test results, it can be found that the economic development of various regions in China does have significant spatial correlation, and its spatial correlation direction is positive, indicating that the economic development of various regions has a certain mutual promotion effect. Each group of data shows that the test results are significant, indicating that there is a spatial spillover effect in China's regional economic development. The 2015 national vector map is drawn and relevant analysis is conducted. The results are shown in Figure 1.

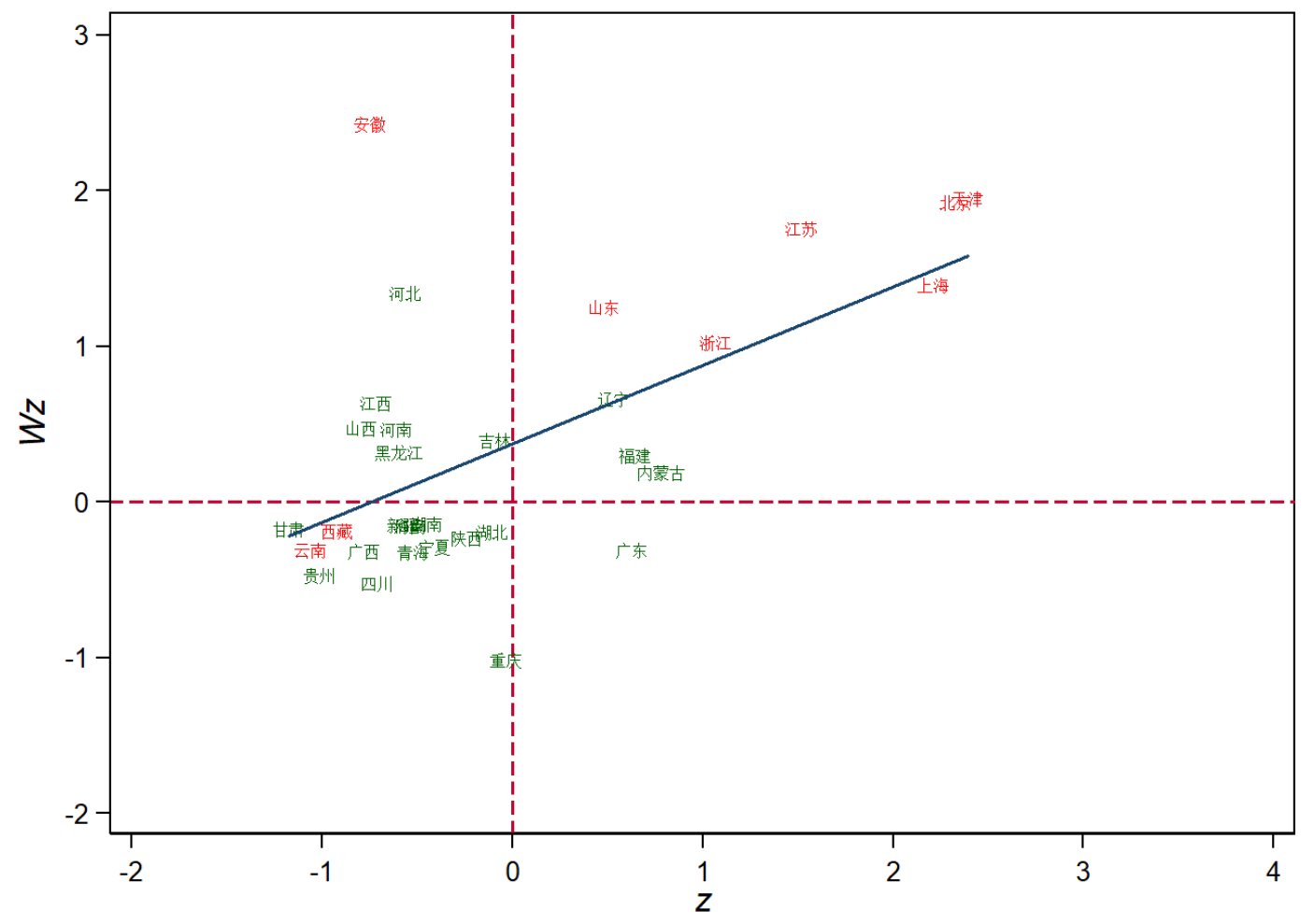

Figure 1. Moran scatter plot of per capita real GDP in various regions of China in 2015

The first quadrant in Figure 1 indicates that the region with high observations is also surrounded by regions with high observations; the second quadrant indicates that regions with high observations are surrounded by regions with low observations; the third quadrant indicates low The region of observations is also surrounded by regions with low observations; the fourth quadrant indicates that regions with low observations are surrounded by 
regions with high observations. As can be seen from the figure, most of the observations fall in the third quadrant, while the data scattered in the second quadrant and the fourth quadrant are less. Therefore, it can be concluded that the above-mentioned economic growth has a relatively obvious spatial autocorrelation effect. The same principle is used to conduct Moran's I test of financial resource scale, Moran's I test of financial practitioners, Moran's I test of financial practitioners, Moran's I test of banking location entropy, Moran's I test of location entropy of securities industry, and Moran's I test of insurance location entropy. Eventually, similar results are obtained.

Here, financial agglomeration is introduced into the production function. Economic output depends not only on production factors such as capital accumulation and labor input, but also on financial agglomeration as an accumulative input of production factors. The production function can be written in the following form:

$$
Y_{i t}=F\left(T_{i t}, K_{i t}, L_{i t}\right)
$$

Among them, $\mathrm{i}$ and $\mathrm{t}$ represent the region and time respectively; $Y_{i t}$ is the gross national product of each province in China. For the province $\mathrm{i}$ in the period, the economic output of the $Y_{i t}$ unit is determined by the financial concentration of the $T_{i t}$ unit, the total investment in the fixed assets of the $K_{i t}$ unit, and the labor input of the $L_{i t}$ unit. For the sake of simplicity, the production function takes the form of Cobb-Douglas:

$$
Y_{i t}=T_{i t}^{1-\beta} K_{i t}^{\beta} L_{i t}^{1-\beta}
$$

Among them, $0<\beta<1$. If the total capital in the above formula is replaced by per capita capital, the production function is as follows:

$$
y_{i t}=t_{i t}^{1-\beta} k_{i t}^{\beta}
$$

By transforming the Cobb-Douglas production function of the above formula, the traditional panel data measurement model is established as follows:

$$
\ln y_{i t}=\beta_{0}+\beta_{1} \ln t_{i t}+\beta_{2} \ln k_{i t}+\varepsilon_{i t}
$$

Due to the huge economic differences in various regions of China, the spatial heterogeneity of regional economy is prominent, and the traditional econometric model ignores the influence of spatial effects. Therefore, in addition to the general econometric model, this paper introduces the financial agglomeration in the case of spatial effects. The role of endogenous economic growth.

Before substituting data into the corresponding spatial econometric model, it is necessary to determine how applicable each model is to the data given herein. In other words, if the data applied to a spatial measurement model uses other types of spatial measurement models, the results will cause different degrees of deviation. Le Sage and Pace (2009) found that if the spatial autocorrelation effect of the dependent variable and the independent variable is neglected, the result is more expensive than the result of ignoring the spatial autocorrelation effect of the error term, and the actual error will be greater. The main reason for this difference is that the former's calculation is equivalent to omitting the explanatory variables, resulting in bias and inconsistency in the estimation; while the latter calculation is only equivalent to the estimated efficiency of the lost part. Therefore, before the data is substituted into the appropriate model for calculation, the applicability of each model is tested.

Modify equation (11) to a spatial model, expressed as follows:

$$
\begin{gathered}
\operatorname{lny}_{i t}=\alpha+\tau \ln y_{i t-1}+\rho \sum_{j=1}^{n} W_{i j} \operatorname{lny}_{j t}+\sum_{K=1}^{K} X_{i t K} \beta_{K}+\sum_{K=1}^{K} \sum_{j=1}^{n} W_{i j} X_{j t K} \theta_{K}+\mu_{i}+\gamma_{i}+\varphi_{i t} \\
\varphi_{i t}=\lambda \sum_{j=1}^{n} m_{i j} \varphi_{i t}+\epsilon_{i t} \quad i=1, \ldots, n \quad t=1, \ldots, T
\end{gathered}
$$

Among them, $\ln y_{i t}$ represents the lag first-order term of $\ln y_{i t}, W_{i j}$ represents the corresponding value of $i, j$ under the spatial weight matrix, and $\theta_{\mathrm{K}}$ represents the spatial lag variable. $\mathrm{X}$ represents all explanatory variables, including the size of financial resources, the size of financial practitioners, location entropy of banking industry, location entropy of securities industry, location entropy of insurance industry, investment in fixed assets per capita, average education level, urbanization rate, per capita exports, localized economy, Porter's externalities, economic base, infrastructure construction and unemployment rate.

When $\lambda$ taking 0 , a space Durbin model (SDM) can be obtained;

When $\rho$ and $\theta$ take 0 at the same time, a spatial error model (SEM) can be obtained;

When $\lambda$ and $\theta$ take 0 at the same time, a spatial lag model (SLM) can be obtained;

When $\theta$ takes 0 , a general space model (SAC) can be obtained.

The first-order partial derivative processing of the explanatory variable $\mathrm{X}$ is performed on the function in the 
formula (12), and the formula 6 is obtained:

$$
\left[\frac{\partial Y}{\partial x_{n K}}\right]=(1-\rho W)^{-1}\left[\begin{array}{cccc}
\beta_{K} & W_{12} \theta_{K} & \cdots & W_{1 n} \theta_{K} \\
W_{21} \theta_{K} & \beta_{K} & \cdots & W_{2 n} \theta_{K} \\
\vdots & \vdots & \ddots & \vdots \\
W_{n 1} \theta_{K} & W_{n 2} \theta_{K} & \cdots & \beta_{K}
\end{array}\right]
$$

When $\lambda$ takes 0 , the expression of the formula under the SDM model can be obtained as follows:

$$
(1-\rho W)^{-1}\left[\begin{array}{cccc}
\beta_{K} & W_{12} \theta_{K} & \cdots & W_{1 n} \theta_{K} \\
W_{21} \theta_{K} & \beta_{K} & \cdots & W_{2 n} \theta_{K} \\
\vdots & \vdots & \ddots & \vdots \\
W_{n 1} \theta_{K} & W_{n 2} \theta_{K} & \cdots & \beta_{K}
\end{array}\right]
$$

When $\rho$ and $\theta$ take 0 at the same time, the expression of the formula under the SEM model can be obtained as follows:

$$
\left[\begin{array}{cccc}
\beta_{K} & 0 & \cdots & 0 \\
0 & \beta_{K} & \cdots & 0 \\
\vdots & \vdots & \ddots & \vdots \\
0 & 0 & \cdots & \beta_{K}
\end{array}\right]
$$

When $\theta$ takes 0 or $\lambda$ and $\theta$ take 0 at the same time, the expression of the formula under the SAC model or SLM model can be obtained as follows:

$$
(1-\rho W)^{-1}\left[\begin{array}{cccc}
\beta_{K} & 0 & \cdots & 0 \\
0 & \beta_{K} & \cdots & 0 \\
\vdots & \vdots & \ddots & \vdots \\
0 & 0 & \cdots & \beta_{K}
\end{array}\right]
$$

In selecting the above four spatial econometric models, Elhorst (2009) also supports the views of Le Sage and Pace (2009), considering that the spatial autocorrelation effects within the dependent and independent variables are first taken into account, and the error term is excluded. The practice of spatial autocorrelation within is more robust. That is, the spatial Doberman model is preferentially estimated. Secondly, two hypotheses can be tested by the LM Test and the Wald Test: $\mathrm{H} 0: \theta+\rho \beta=0$ and $\mathrm{H} 0: \theta=0$, respectively, to verify whether the SDM model can be separated. Simplified into SEM model and SLM model. If the test results pass this assumption, it is considered that the SDM model can be transformed into a model corresponding to the test, that is, the data is suitable when using the SEM model or the SLM model. The rationality of the LM test and the Wald test is derived as follows:

(1) LM test:

If $\theta+\rho \beta=0$ is established,

then SDM: $Y=\rho W y+X \beta+W X \theta+\varepsilon$, let $\varepsilon=\mu(1-\rho W)$

$\Rightarrow Y=\rho W y+X \beta-\rho W X \beta+\varepsilon \Rightarrow Y(1-\rho W)=X \beta(1-\rho W)+\varepsilon$

$\Rightarrow\left\{\begin{array}{l}Y=X \beta+\mu \\ \mu=\rho W \mu+\varepsilon\end{array}\right.$, that is, SEM is obtained.

(2) Wald test:

If $\theta=0$ is established, then SDM: $Y=\rho W y+X \beta+W X \theta+\varepsilon$

$\Rightarrow \mathrm{Y}=\rho \mathrm{Wy}+\mathrm{X} \beta+\varepsilon$, that is, SLM is obtained.

Through the analysis and integration of the four spatial econometric models, it can be found that $\beta, \rho$ and $\theta$ in the spatial Dubin model (SDM) can be transformed into the other two models under different conditions. Specifically, when $\theta=0$, the spatial Dubin model can be transformed into a spatial lag model (SLM); and when $\theta+\rho \beta=0$, a spatial error model (SEM) of the set of data can be constructed; When $\beta, \rho$ and $\theta$ satisfy the variable conditions of the spatial lag model and the spatial error model at the same time, the general space model (SAC) can be constructed to interpret and analyze the data.

Therefore, when performing data operations, the data of the explanatory variable, the explained variable and the control variable are first substituted into the spatial Durbin model (SDM) to obtain the value of the spatial lag variable $\theta$ and related information. Based on the SDM model, the LM test can be used to test whether the spatial Durbin model can be transformed into a spatial error model (SEM) using the assumption of $\theta+\rho \beta=0$. 
Each variable selected all passes the LM test, indicating that the condition $a+b=c$ is true, and the use of the spatial error model is theoretically reasonable. Assuming that the condition $\theta=0$ can be established and whether the use of the spatial lag model (SLM) is reasonable, the Wald test is also passed. Therefore, the variables selected in this paper can also use the spatial lag model (SLM) for spatial measurement and theoretical exploration. Meanwhile, in the case where the condition $\theta=0$ and $\theta+\rho \beta=0$ are satisfied, the general space model (SAC) can be used.

Through LM and Wald test, it is found that all four spatial econometric models are applicable to the research data, so the next step is to construct financial agglomeration: a spatial model for the impact of regional economic growth. At the same time, for each model, it is divided into three cases: regional fixed, fixed time and double fixed. Among them, the regional fixed indicates the relationship between the variables with the change of the region, the relationship between the variables changes with time is reflected by the fixed point, while the double fixed model of the region and the time shows that effect of the regional and temporal changes on the variables. The regression results of the SEM and the SLM model are shown in Table 3. The regression results of the SAC and the SDM model are shown in Table 4:

Table 3. Financial agglomeration and regional economic development

\begin{tabular}{|c|c|c|c|c|c|c|c|}
\hline \multirow{2}{*}{ Variable } & \multirow{2}{*}{$\begin{array}{c}\text { Traditional individual } \\
\text { Fixed effect }\end{array}$} & \multicolumn{3}{|c|}{ SEM } & \multicolumn{3}{|c|}{ SLM } \\
\hline & & Region fixed & Time fixed & Double fixed & Region fixed & Time fixed & Double fixed \\
\hline \multirow[t]{2}{*}{ RES } & 34579.3 & $41577.9^{* *}$ & $-51156.7^{* *}$ & $41806.9^{* *}$ & $45349.8^{* *}$ & -23507.3 & $44333.5^{* *}$ \\
\hline & $(1.41)$ & (2.19) & $(-2.28)$ & $(2.24)$ & $(2.38)$ & $(-1.03)$ & $(2.37)$ \\
\hline \multirow[t]{2}{*}{ PAR } & $220320.8^{* *}$ & $184944.0^{* * * *}$ & $124586.6^{* * *}$ & $160424.7^{* *}$ & $152311.4^{* *}$ & $107197.8^{* * * *}$ & $172834.6^{* * *}$ \\
\hline & $(2.56)$ & $(2.74)$ & $(4.36)$ & $(2.42)$ & $(2.27)$ & (3.77) & $(2.59)$ \\
\hline \multirow[t]{2}{*}{ BAN } & $-13711.9^{* * * *}$ & $-8224.3^{* * * *}$ & $1760.3^{* * *}$ & $-10890.2^{* * *}$ & $-8289.0^{* * * *}$ & $1557.0^{* *}$ & $-8893.5^{* * *}$ \\
\hline & $(-8.87)$ & $(-6.20)$ & $(2.84)$ & $(-8.75)$ & $(-6.41)$ & $(2.56)$ & $(-6.87)$ \\
\hline \multirow[t]{2}{*}{ SEC } & $-303.2^{* * *}$ & $-196.1^{* *}$ & $434.2^{* * *}$ & -130.6 & $-165.7^{*}$ & $488.3^{* * *}$ & $-179.9^{* *}$ \\
\hline & $(-2.75)$ & $(-2.38)$ & $(3.62)$ & $(-1.44)$ & $(-1.92)$ & $(4.13)$ & $(-2.14)$ \\
\hline \multirow[t]{2}{*}{ INS } & $969.0^{* * *}$ & $674.0^{* * *}$ & -200.9 & $755.2^{* * *}$ & $744.0^{* * *}$ & -401.9 & $722.4^{* * *}$ \\
\hline & $(4.53)$ & $(4.17)$ & $(-0.80)$ & $(4.49)$ & $(4.44)$ & $(-1.59)$ & $(4.43)$ \\
\hline \multirow[t]{2}{*}{ INV } & $0.733^{* * *}$ & $0.635^{* * *}$ & $0.792^{* * *}$ & $0.586^{* * *}$ & $0.549^{* * *}$ & $0.786^{* * *}$ & $0.611^{* * *}$ \\
\hline & (17.86) & $(15.41)$ & (17.48) & (14.03) & (15.35) & (17.74) & (15.64) \\
\hline \multirow[t]{2}{*}{ EDU } & $-9965.2^{* *}$ & -3651.4 & $-5240.3^{* *}$ & -3512.9 & -4497.9 & -2108.8 & -3264.0 \\
\hline & $(-2.36)$ & $(-1.11)$ & $(-2.46)$ & $(-1.05)$ & $(-1.36)$ & $(-0.99)$ & $(-0.99)$ \\
\hline \multirow[t]{2}{*}{ EXP } & $0.328^{* * *}$ & $0.226^{* * *}$ & $0.372^{* * *}$ & $0.150^{* * * *}$ & $0.234^{* * *}$ & $0.376^{* * *}$ & $0.194^{* * *}$ \\
\hline & (4.69) & (3.80) & (11.44) & $(2.58)$ & $(4.25)$ & (11.54) & (3.39) \\
\hline \multirow[t]{2}{*}{ URB } & 4574.2 & $-63700.3^{* * * *}$ & $29221.7^{* * *}$ & $-77747.8^{* * * *}$ & $-61746.2^{* * *}$ & $27216.9^{* * *}$ & $-68976.9^{* * * *}$ \\
\hline & $(0.33)$ & $(-4.52)$ & (5.85) & $(-6.51)$ & $(-5.02)$ & $(5.55)$ & $(-5.27)$ \\
\hline \multirow[t]{2}{*}{ LOE } & $11197.3^{* * *}$ & $7642.2^{* * *}$ & $-3680.2^{* *}$ & $13016.5^{* * *}$ & $12175.0^{* * *}$ & $-5798.6^{* * *}$ & $9808.5^{* * *}$ \\
\hline & (3.66) & (3.15) & $(-2.07)$ & $(4.70)$ & (5.12) & $(-3.25)$ & (3.95) \\
\hline \multirow[t]{2}{*}{ POE } & $-5645.3^{* * *}$ & $-2849.6^{* *}$ & $-3851.7^{* * *}$ & $-2300.4^{* * *}$ & $-3420.0^{* * * *}$ & $-5696.0^{* * *}$ & $-2759.6^{* *}$ \\
\hline & $(-3.99)$ & $(-2.49)$ & $(-3.52)$ & $(-2.05)$ & $(-3.06)$ & $(-5.26)$ & $(-2.45)$ \\
\hline \multirow[t]{2}{*}{ LIC } & $5.674^{* * *}$ & 1.305 & -2.944 & -1.785 & -0.631 & -1.438 & -0.235 \\
\hline & (2.69) & $(0.68)$ & $(-1.12)$ & $(-0.99)$ & $(-0.36)$ & $(-0.55)$ & $(-0.13)$ \\
\hline \multirow[t]{2}{*}{$S \& T$} & $0.0383^{* * *}$ & $0.0460^{* * *}$ & $0.0403^{* * *}$ & $0.0703^{* * *}$ & $0.0541^{* * *}$ & $0.0367^{* * *}$ & $0.0569^{* * *}$ \\
\hline & (3.18) & (4.64) & $(3.50)$ & (7.16) & $(5.72)$ & $(3.27)$ & (5.83) \\
\hline \multirow[t]{2}{*}{ UER } & 792.0 & $1840.5^{* * *}$ & 599.4 & $3088.2^{* * * *}$ & $2119.3^{* * * *}$ & $1347.4^{* *}$ & $2422.1^{* * * *}$ \\
\hline & $(0.97)$ & $(2.81)$ & $(0.95)$ & $(4.57)$ & $(3.27)$ & $(2.15)$ & (3.73) \\
\hline Variance & 0.9442 & 0.9184 & 0.8966 & 0.8505 & 0.9536 & 0.9146 & 0.9434 \\
\hline sigma2_e & & $6138066.0^{* * *}$ & $19744740.0^{* * * *}$ & $5471941.0^{* * * *}$ & $6066790.6^{* * *}$ & $18979770.8^{* * *}$ & $5675907.1^{* * *}$ \\
\hline
\end{tabular}


Table 4. Financial agglomeration and regional economic development

\begin{tabular}{|c|c|c|c|c|c|c|c|}
\hline \multirow{2}{*}{ Variable } & \multirow{2}{*}{$\begin{array}{c}\text { Traditional individual } \\
\text { Fixed effect } \\
\end{array}$} & \multicolumn{3}{|c|}{ SAC } & \multicolumn{3}{|c|}{ SDM } \\
\hline & & Region fixed & Time fixed & Double fixed & Region fixed & Time fixed & Double fixed \\
\hline \multirow[t]{2}{*}{ RES } & -6970.1 & $45578.6^{* *}$ & -24837.1 & $41368.5^{* *}$ & 13206.4 & -31006.9 & $27655.8^{*}$ \\
\hline & $(-0.24)$ & $(2.41)$ & $(-1.10)$ & $(2.27)$ & $(0.75)$ & $(-1.38)$ & (1.68) \\
\hline \multirow[t]{2}{*}{ PAR } & $259585.3^{* * * *}$ & $166218.2^{* *}$ & $99054.4^{* * *}$ & $203325.8^{* * *}$ & $322132.1^{* * *}$ & $139529.7^{* * *}$ & $332136.2^{* * *}$ \\
\hline & (3.48) & $(2.48)$ & $(3.51)$ & (3.09) & $(4.97)$ & $(4.41)$ & $(5.42)$ \\
\hline \multirow[t]{2}{*}{ BAN } & $-3427.2^{*}$ & $-8064.5^{* * * *}$ & $1610.9^{* * * *}$ & $-9477.9^{* * * *}$ & $-7435.9^{* * *}$ & $1432.1^{* * *}$ & $-6854.0^{* * * *}$ \\
\hline & $(-1.81)$ & $(-6.17)$ & $(2.67)$ & $(-7.75)$ & $(-5.98)$ & $(2.33)$ & $(-5.61)$ \\
\hline \multirow[t]{2}{*}{ SEC } & -15.81 & $-183.3^{* *}$ & $427.5^{* * *}$ & -118.4 & -56.98 & $492.6^{* * *}$ & -27.79 \\
\hline & $(-0.13)$ & $(-2.16)$ & (3.64) & $(-1.34)$ & $(-0.68)$ & $(4.16)$ & $(-0.34)$ \\
\hline \multirow[t]{2}{*}{ INS } & $406.8^{*}$ & $719.8^{* * *}$ & -320.1 & $757.2^{* * * *}$ & $698.1^{* * *}$ & -217.4 & $610.9^{* * *}$ \\
\hline & $(1.88)$ & $(4.38)$ & $(-1.30)$ & $(4.59)$ & $(4.06)$ & $(-0.88)$ & $(3.74)$ \\
\hline \multirow[t]{2}{*}{ INV } & $0.646^{* * *}$ & $0.589^{* * * *}$ & $0.776^{* * *}$ & $0.565^{* * *}$ & $0.490^{* * *}$ & $0.734^{* * *}$ & $0.439^{* * *}$ \\
\hline & $(16.78)$ & (14.27) & (17.63) & $(13.20)$ & (11.63) & (14.54) & $(9.64)$ \\
\hline \multirow[t]{2}{*}{ EDU } & $-9841.9^{* * * *}$ & -3955.6 & -3318.0 & -2836.8 & -4328.2 & -461.3 & -5908.5 \\
\hline & $(-2.76)$ & $(-1.20)$ & $(-1.55)$ & $(-0.86)$ & $(-1.31)$ & $(-0.21)$ & $(-1.62)$ \\
\hline \multirow[t]{2}{*}{ EXP } & $0.413^{* * *}$ & $0.235^{* * *}$ & $0.382^{* * *}$ & $0.147^{* * * *}$ & $0.194^{* * *}$ & $0.394^{* * *}$ & $0.194^{* * *}$ \\
\hline & (6.76) & (4.15) & $(12.00)$ & $(2.63)$ & (3.37) & $(8.56)$ & (3.44) \\
\hline \multirow[t]{2}{*}{ URB } & $43722.1^{* * *}$ & $-61576.6^{* * *}$ & $27137.6^{* * *}$ & $-69762.3^{* * *}$ & $-56430.1^{* * *}$ & $28509.1^{* * * *}$ & $-66635.5^{* * *}$ \\
\hline & (3.54) & $(-4.89)$ & (5.55) & $(-5.96)$ & $(-4.20)$ & (5.94) & $(-5.25)$ \\
\hline \multirow[t]{2}{*}{ LOE } & -1420.8 & $10231.4^{* * * *}$ & $-5051.2^{* * * *}$ & $11893.3^{* * *}$ & $13390.3^{\text {*** }}$ & $-10522.1^{* * *}$ & $13557.8^{* * *}$ \\
\hline & $(-0.35)$ & (3.99) & $(-2.86)$ & $(4.45)$ & (5.32) & $(-5.50)$ & $(4.70)$ \\
\hline \multirow[t]{2}{*}{ POE } & $-5847.1^{* * * *}$ & $-3258.1^{* * * *}$ & $-5060.1^{* * *}$ & $-2596.1^{* *}$ & -1211.4 & $-3280.0^{* * * *}$ & -962.0 \\
\hline & $(-4.20)$ & $(-2.91)$ & $(-4.59)$ & $(-2.36)$ & $(-1.12)$ & $(-3.15)$ & $(-0.96)$ \\
\hline \multirow[t]{2}{*}{ LIC } & $7.895^{* * *}$ & 0.0127 & -1.023 & -0.194 & 2.648 & $-4.611^{*}$ & $3.220^{*}$ \\
\hline & $(3.29)$ & $(0.01)$ & $(-0.40)$ & $(-0.11)$ & (1.43) & $(-1.93)$ & (1.72) \\
\hline \multirow[t]{2}{*}{$S \& T$} & 0.00258 & $0.0517^{* * *}$ & $0.0343^{* * *}$ & $0.0601^{* * * *}$ & $0.0299^{* * * *}$ & $0.0414^{* * * *}$ & $0.0357^{* * * *}$ \\
\hline & $(0.21)$ & (5.37) & (3.06) & $(6.26)$ & (3.06) & (2.87) & (3.51) \\
\hline \multirow[t]{2}{*}{ UER } & 405.1 & $2079.8^{* * *}$ & 1026.1 & $2744.1^{* * *}$ & $1024.2^{*}$ & $1913.4^{* * *}$ & $2042.3^{* * *}$ \\
\hline & $(0.43)$ & $(3.22)$ & $(1.64)$ & $(4.22)$ & $(1.67)$ & (3.03) & (3.19) \\
\hline Variance & 0.9233 & 0.9522 & 0.9137 & 0.9428 & 0.9698 & 0.6260 & 0.6189 \\
\hline sigma2_e & & $6653070.6^{* * *}$ & $18702826.0^{* * * *}$ & $5695206.1^{* * *}$ & $4624901.1^{* * *}$ & $13102989.0^{* * * *}$ & $3796059.2^{* * *}$ \\
\hline
\end{tabular}

Note. $* * *, * *, *$ denotes significant at $1 \%, 5 \%, 10 \%$ significance level, respectively.

Through the construction and test of four spatial econometric models, such as spatial lag model, spatial error model, spatial Durbin model and general space model, the related information of each interpretative variable and explanatory variable is obtained, including correlation coefficient and z-test value, goodness of fit, and maximum likelihood values. Then, using the Log maximum likelihood value obtained by the test, the Akaike (AIC) and Bayesian (BIC) information criterion can be tested to obtain a suitable optimal model. The results of the AIC and BIC information guidelines can be summarized as Table 5:

Table 5. Spatial measurement model information criterion value simulation result

\begin{tabular}{|c|c|c|c|}
\hline Spatial measurement model & Fixed effect & AIC value & $\mathrm{BIC}$ value \\
\hline \multirow{3}{*}{ SEM } & Region fixed & 5786.023 & 5838.335 \\
\hline & Time fixed & 6117.291 & 6165.867 \\
\hline & Double fixed & 5729.352 & 5785.4 \\
\hline \multirow{3}{*}{ SLM } & Region fixed & 5754.831 & 5807.143 \\
\hline & Time fixed & 6102.274 & 6147.113 \\
\hline & Double fixed & 5731.847 & 5787.896 \\
\hline \multirow{3}{*}{ SAC } & Region fixed & 5753.746 & 5809.794 \\
\hline & Time fixed & 6098.937 & 6147.512 \\
\hline & Double fixed & 5722.674 & 5782.459 \\
\hline \multirow{3}{*}{ SDM } & Region fixed & 5689.844 & 5786.995 \\
\hline & Time fixed & 6010.324 & 6103.738 \\
\hline & Double fixed & 5644.458 & 5745.346 \\
\hline
\end{tabular}


From the definition of AIC and BIC information criterion, when the AIC value or BIC value is the smallest, the optimal model suitable for the variable can often be obtained. Therefore, from the test results in the above table, it can be found that the AIC value (5689.844) and the BIC value (5786.995) of the SDM model are the minimum of the four models when studying the fixed effect in the region, so the SDM can be used under the regional fixed effect. As the optimal space model for interpreting the relationship between variables; similarly, the AIC value and BIC value of SDM are the minimum of the four models under the fixed time and double fixed effect, indicating that the SDM model is also fixed at the same time and double The optimal space model that meets the variable data requirements under fixed effects. Therefore, the spatial Durbin model (SDM) was chosen as the model for studying spatial variables.

The SDM model is used as a spatial econometric model for data research. However, from the test results of the spatial Durbin model, the correlation coefficient of some explanatory variables is inconsistent with the research expectation, and the significance of the tested variables is not obvious. It is speculated that the regional differences will lead to the national total data. There is a certain error in the test. Therefore, according to the China Statistical Yearbook, 31 provinces, municipalities and autonomous regions are divided into the eastern region, the central region and the western region, and the spatial Durbin model is constructed for each region, so as to explore the cumulative effect of spatial variables., including direct effects, indirect effects, and total effects. The spatial lag model can be rewritten as:

$$
Y=\left[\left(I_{N}-\lambda W\right)\right]^{-1}(X \beta+\varepsilon)
$$

The direct and total effects can be expressed as:

$$
\begin{gathered}
\frac{\partial y_{i}}{\partial x_{j k}}=\left[\left(I_{N}-\lambda W\right)\right]_{j, j}^{-1} * \beta_{k} \\
\frac{\partial y_{i}}{\partial x_{k}}=\left[\left(I_{N}-\lambda W\right)\right]_{j, j}^{-1} * e_{n} \beta_{k}
\end{gathered}
$$

The indirect effect is equal to the difference between the total effect and the direct effect. $I_{N}$ is an identity matrix of $n * n, e_{n}$ is a matrix of $n * 1$, and all en elements have a value of 1 . The other elements of the model are similar to SLM. The direct, indirect, and total effects of financial agglomeration are calculated using equations (8) and (9). Cumulative effect analysis indicates that explanatory variables affect not only one observation (direct effect), but also that the impact profile affects other observations (indirect effects). The indirect effect can be explained here as the spillover effect of the variable. The total effect is the sum of direct and indirect effects.

Regression analysis is performed on the financial agglomeration indicator data and economic data in each region using the dual fixed effect panel SDM model in units of regions. The regression results are shown in Table 6 . The direct effect indicates the direct effect of each explanatory variable on the economic growth of the region. Indirect effect represents the indirect effect of each explanatory variable on the economic growth of the neighboring region through spatial spillover effect. The overall effect represents the combined effect of each explanatory variable on the economic growth of the region and its vicinity.

Table 6. Cumulative effect

\begin{tabular}{ccccc}
\hline & The national & The eastern region & The central region & The western region \\
\hline$\beta$ & & & & -25102.1 \\
RES & $27655.8^{*}$ & $-30438.5^{*}$ & $334879.6^{* * *}$ & $(-0.88)$ \\
& $(1.68)$ & $(-1.85)$ & $(2.50)$ & -155613.7 \\
PAR & $332136.2^{* * *}$ & -81183.3 & 94648.0 & $(-1.18)$ \\
& $(5.42)$ & $(-0.98)$ & $(0.61)$ & -2656.8 \\
BAN & $-6854.0^{* * *}$ & $-6417.4^{* * *}$ & $17905.4^{* *}$ & $(-1.11)$ \\
& $(-5.61)$ & $(-4.05)$ & $(2.13)$ & 189.5 \\
SEC & -27.79 & 60.05 & 267.2 & $(1.22)$ \\
& $(-0.34)$ & $(0.74)$ & $(0.28)$ & -447.8 \\
INS & $610.9^{* * *}$ & $(1.42)$ & -857.8 & $(-0.25)$ \\
& $(3.74)$ & $0.333^{* * *}$ & $(-1.42)$ & $0.352^{* * *}$ \\
INV & $0.439^{* * *}$ & $(5.33)$ & $\left(9.411^{* * *}\right.$ & $(3.58)$ \\
& $(9.64)$ & 4775.7 & $-16488.7^{* *}$ & -7397.7 \\
EDU & -5908.5 & $(0.50)$ & $(-1.99)$ & $(-1.34)$ \\
\hline
\end{tabular}




\begin{tabular}{|c|c|c|c|c|}
\hline EXP & $\begin{array}{c}0.194^{* * *} \\
(3.44)\end{array}$ & $\begin{array}{l}0.0625 \\
(0.85)\end{array}$ & $\begin{array}{l}-0.515 \\
(-1.55)\end{array}$ & $\begin{array}{c}0.0444 \\
(0.52)\end{array}$ \\
\hline URB & $\begin{array}{c}-66635.5^{* * *} \\
(-5.25)\end{array}$ & $\begin{array}{c}-224663.6^{* * *} \\
(-9.29)\end{array}$ & $\begin{array}{c}3790.7 \\
(0.21)\end{array}$ & $\begin{array}{c}33696.3 \\
(1.46)\end{array}$ \\
\hline LOE & $\begin{array}{c}13557.8^{* * * *} \\
(4.70)\end{array}$ & $\begin{array}{c}-4773.4 \\
(-0.63)\end{array}$ & $\begin{array}{c}16387.2^{* * * *} \\
(2.95)\end{array}$ & $\begin{array}{c}12755.4^{* * *} \\
(2.95)\end{array}$ \\
\hline POE & $\begin{array}{l}-962.0 \\
(-0.96)\end{array}$ & $\begin{array}{c}-13414.5^{* * *} \\
(-5.50)\end{array}$ & $\begin{array}{c}-12935.8^{* * *} \\
(-4.15)\end{array}$ & $\begin{array}{l}-745.4 \\
(-0.89)\end{array}$ \\
\hline LIC & $\begin{array}{l}3.220^{*} \\
(1.72)\end{array}$ & $\begin{array}{l}-3.504 \\
(-1.32)\end{array}$ & $\begin{array}{c}16.44^{* * *} \\
(2.73)\end{array}$ & $\begin{array}{l}-0.713 \\
(-0.25)\end{array}$ \\
\hline S\&T & $\begin{array}{c}0.0357^{* * *} \\
(3.51)\end{array}$ & $\begin{array}{c}0.00260 \\
(0.19)\end{array}$ & $\begin{array}{c}-0.242^{* * *} \\
(-3.86)\end{array}$ & $\begin{array}{c}0.155^{* * *} \\
(4.50)\end{array}$ \\
\hline UER & $\begin{array}{c}2042.3^{* * *} \\
(3.19) \\
\end{array}$ & $\begin{array}{c}4384.1^{* * *} \\
(4.50) \\
\end{array}$ & $\begin{array}{l}214.1 \\
(0.23) \\
\end{array}$ & $\begin{array}{r}1240.1^{*} \\
(1.72) \\
\end{array}$ \\
\hline$\theta$ & & & & \\
\hline RES & $\begin{array}{c}-66885.1 \\
(-0.49)\end{array}$ & $\begin{array}{c}-248894.3^{* * *} \\
(-3.62)\end{array}$ & $\begin{array}{c}734168.6 \\
(1.43)\end{array}$ & $\begin{array}{c}-37415.2 \\
(-0.25)\end{array}$ \\
\hline PAR & $\begin{array}{c}1740880.3^{* * *} \\
(3.20)\end{array}$ & $\begin{array}{c}-181085.0 \\
(-0.44)\end{array}$ & $\begin{array}{c}271202.7 \\
(0.35)\end{array}$ & $\begin{array}{c}-443869.6 \\
(-0.72)\end{array}$ \\
\hline BAN & $\begin{array}{c}-23859.5^{* * *} \\
(-3.40)\end{array}$ & $\begin{array}{c}3617.4 \\
(0.69)\end{array}$ & $\begin{array}{c}-53128.2 \\
(-1.52)\end{array}$ & $\begin{array}{c}5206.0 \\
(0.52)\end{array}$ \\
\hline SEC & $\begin{array}{l}441.1 \\
(1.11)\end{array}$ & $\begin{array}{l}303.6 \\
(1.47)\end{array}$ & $\begin{array}{l}445.0 \\
(0.08)\end{array}$ & $\begin{array}{l}11.21 \\
(0.02)\end{array}$ \\
\hline INS & $\begin{array}{c}1112.4 \\
(0.99)\end{array}$ & $\begin{array}{l}91.09 \\
(0.06)\end{array}$ & $\begin{array}{c}2914.1 \\
(0.96)\end{array}$ & $\begin{array}{l}-865.5 \\
(-0.09)\end{array}$ \\
\hline INV & $\begin{array}{c}-0.0978 \\
(-0.29)\end{array}$ & $\begin{array}{l}-0.577^{*} \\
(-1.93)\end{array}$ & $\begin{array}{c}0.727^{* * *} \\
(3.78)\end{array}$ & $\begin{array}{c}-1.327^{* * *} \\
(-2.78)\end{array}$ \\
\hline EDU & $\begin{array}{c}-63330.9^{*} \\
(-1.66)\end{array}$ & $\begin{array}{c}36605.2 \\
(0.95)\end{array}$ & $\begin{array}{c}-20490.8 \\
(-0.64)\end{array}$ & $\begin{array}{l}-7122.4 \\
(-0.29)\end{array}$ \\
\hline EXP & $\begin{array}{l}0.138 \\
(0.40)\end{array}$ & $\begin{array}{c}1.263^{* * *} \\
(5.37)\end{array}$ & $\begin{array}{l}1.334 \\
(1.00)\end{array}$ & $\begin{array}{l}-0.172 \\
(-0.50)\end{array}$ \\
\hline URB & $\begin{array}{c}-57468.6 \\
(-0.67)\end{array}$ & $\begin{array}{c}-405022.5^{* * *} \\
(-4.10)\end{array}$ & $\begin{array}{c}-227287.6^{* * * *} \\
(-3.69)\end{array}$ & $\begin{array}{c}-148464.3 \\
(-1.14)\end{array}$ \\
\hline LOE & $\begin{array}{c}77487.5^{* * *} \\
(3.22)\end{array}$ & $\begin{array}{c}-25956.4 \\
(-0.79)\end{array}$ & $\begin{array}{c}-8695.7 \\
(-0.42)\end{array}$ & $\begin{array}{c}34894.6^{*} \\
(1.95)\end{array}$ \\
\hline POE & $\begin{array}{c}10244.5 \\
(1.08)\end{array}$ & $\begin{array}{c}-21110.8 \\
(-1.49)\end{array}$ & $\begin{array}{c}-59096.9^{* * * *} \\
(-4.34)\end{array}$ & $\begin{array}{c}-2191.6 \\
(-0.31)\end{array}$ \\
\hline LIC & $\begin{array}{l}11.69 \\
(0.70)\end{array}$ & $\begin{array}{c}-38.99^{* *} \\
(-2.07)\end{array}$ & $\begin{array}{l}-23.92 \\
(-0.85)\end{array}$ & $\begin{array}{l}-6.164 \\
(-0.35)\end{array}$ \\
\hline S\&T & $\begin{array}{c}0.0421 \\
(0.86)\end{array}$ & $\begin{array}{c}0.00993 \\
(0.24)\end{array}$ & $\begin{array}{l}-0.245 \\
(-0.91)\end{array}$ & $\begin{array}{c}0.0649 \\
(0.48)\end{array}$ \\
\hline UER & $\begin{array}{c}23986.0^{* * * k} \\
(3.82) \\
\end{array}$ & $\begin{array}{c}6085.0 \\
(1.44) \\
\end{array}$ & $\begin{array}{c}-9290.8^{* *} \\
(-2.20) \\
\end{array}$ & $\begin{array}{c}4463.5 \\
(1.12) \\
\end{array}$ \\
\hline Direct eff & & & & \\
\hline RES & $\begin{array}{c}30332.8^{*} \\
(1.81)\end{array}$ & $\begin{array}{c}-13058.5 \\
(-0.78)\end{array}$ & $\begin{array}{c}290076.8^{* * *} \\
(2.64)\end{array}$ & $\begin{array}{c}-22691.9 \\
(-0.88)\end{array}$ \\
\hline PAR & $\begin{array}{c}293199.4^{* * *} \\
(4.99)\end{array}$ & $\begin{array}{c}-73361.5 \\
(-1.05)\end{array}$ & $\begin{array}{c}72508.5 \\
(0.67)\end{array}$ & $\begin{array}{c}-137255.3 \\
(-1.18)\end{array}$ \\
\hline BAN & $\begin{array}{c}-6331.6^{* * * *} \\
(-5.37)\end{array}$ & $\begin{array}{c}-6902.6^{* * *} \\
(-4.61)\end{array}$ & $\begin{array}{c}26579.7^{* * *} \\
(3.57)\end{array}$ & $\begin{array}{l}-2861.2 \\
(-1.42)\end{array}$ \\
\hline SEC & $\begin{array}{l}-36.94 \\
(-0.46)\end{array}$ & $\begin{array}{l}41.21 \\
(0.53)\end{array}$ & $\begin{array}{l}209.9 \\
(0.18)\end{array}$ & $\begin{array}{l}195.2 \\
(1.46)\end{array}$ \\
\hline INS & $\begin{array}{c}592.8^{* * *} \\
(4.02)\end{array}$ & $\begin{array}{l}740.1 \\
(1.43)\end{array}$ & $\begin{array}{c}-1307.6^{* *} \\
(-2.27)\end{array}$ & $\begin{array}{l}-439.6 \\
(-0.30)\end{array}$ \\
\hline INV & $\begin{array}{l}0.451^{* * *} \\
(10.29)\end{array}$ & $\begin{array}{c}0.395^{* * *} \\
(6.95)\end{array}$ & $\begin{array}{c}0.370^{* * * *} \\
(8.32)\end{array}$ & $\begin{array}{c}0.450^{* * *} \\
(4.75)\end{array}$ \\
\hline
\end{tabular}




\begin{tabular}{|c|c|c|c|c|}
\hline \multirow{2}{*}{ EDU } & -4374.1 & 2232.9 & $-16008.6^{* * *}$ & -7077.1 \\
\hline & $(-1.33)$ & $(0.27)$ & $(-2.68)$ & $(-1.56)$ \\
\hline \multirow{2}{*}{ EXP } & $0.192^{* * *}$ & -0.0332 & $-0.749^{* *}$ & 0.0533 \\
\hline & (3.49) & $(-0.36)$ & $(-2.42)$ & $(0.70)$ \\
\hline URB & $\begin{array}{c}-65668.1^{* * * *} \\
(-4.89)\end{array}$ & $\begin{array}{c}-204347.3^{* * * *} \\
(-8.92)\end{array}$ & $\begin{array}{c}33722.5 \\
(1.58)\end{array}$ & $\begin{array}{c}45251.9^{* *} \\
(2.48)\end{array}$ \\
\hline LOE & $\begin{array}{c}11866.6^{* * *} \\
(4.53)\end{array}$ & $\begin{array}{c}-3416.6 \\
(-0.49)\end{array}$ & $\begin{array}{c}19515.6^{* * * *} \\
(4.25)\end{array}$ & $\begin{array}{c}10885.2^{* * *} \\
(3.02)\end{array}$ \\
\hline POE & $\begin{array}{c}-1303.7 \\
(-1.36)\end{array}$ & $\begin{array}{c}-12677.8^{* * *} \\
(-5.59)\end{array}$ & $\begin{array}{c}-7250.9^{* * * *} \\
(-2.70)\end{array}$ & $\begin{array}{l}-694.2 \\
(-1.09)\end{array}$ \\
\hline LIC & $\begin{array}{l}3.083^{*} \\
(1.69)\end{array}$ & $\begin{array}{l}-0.858 \\
(-0.38)\end{array}$ & $\begin{array}{c}21.47^{* * * *} \\
(4.27)\end{array}$ & $\begin{array}{l}-0.124 \\
(-0.05)\end{array}$ \\
\hline $\mathrm{S} \& \mathrm{~T}$ & $\begin{array}{c}0.0350^{* * * *} \\
(3.60)\end{array}$ & $\begin{array}{c}0.00199 \\
(0.15)\end{array}$ & $\begin{array}{c}-0.245^{* * *} \\
(-5.33)\end{array}$ & $\begin{array}{c}0.154^{* * *} \\
(4.62)\end{array}$ \\
\hline UER & $\begin{array}{c}1511.3^{* * *} \\
(2.46)\end{array}$ & $\begin{array}{c}4196.8^{* * * *} \\
(4.79)\end{array}$ & $\begin{array}{l}1459.0 \\
(1.55)\end{array}$ & $\begin{array}{l}1008.6 \\
(1.45)\end{array}$ \\
\hline \multicolumn{5}{|c|}{ Indirect effect } \\
\hline RES & $\begin{array}{c}-55133.0 \\
(-0.66)\end{array}$ & $\begin{array}{c}-162291.2^{* * * *} \\
(-3.23)\end{array}$ & $\begin{array}{c}261270.4 \\
(0.99)\end{array}$ & $\begin{array}{c}-19841.8 \\
(-0.20)\end{array}$ \\
\hline PAR & $\begin{array}{c}967218.5^{* *} \\
(2.47)\end{array}$ & $\begin{array}{c}-95958.1 \\
(-0.35)\end{array}$ & $\begin{array}{c}137547.5 \\
(0.31)\end{array}$ & $\begin{array}{c}-249324.5 \\
(-0.60)\end{array}$ \\
\hline BAN & $\begin{array}{r}-11833.8^{* *} \\
(-2.17)\end{array}$ & $\begin{array}{r}5621.4^{*} \\
(1.72)\end{array}$ & $\begin{array}{c}-43812.6^{* *} \\
(-2.21)\end{array}$ & $\begin{array}{l}5716.2 \\
(0.88)\end{array}$ \\
\hline SEC & $\begin{array}{l}286.8 \\
(1.15)\end{array}$ & $\begin{array}{l}180.9 \\
(1.32)\end{array}$ & $\begin{array}{l}243.5 \\
(0.07)\end{array}$ & $\begin{array}{l}-110.8 \\
(-0.29)\end{array}$ \\
\hline INS & $\begin{array}{l}397.9 \\
(0.58)\end{array}$ & $\begin{array}{l}-206.1 \\
(-0.19)\end{array}$ & $\begin{array}{l}2292.7 \\
(1.24)\end{array}$ & $\begin{array}{l}-875.2 \\
(-0.13)\end{array}$ \\
\hline INV & $\begin{array}{l}-0.252 \\
(-1.27)\end{array}$ & $\begin{array}{c}-0.551^{* * *} \\
(-2.78)\end{array}$ & $\begin{array}{l}0.235^{*} \\
(1.91)\end{array}$ & $\begin{array}{c}-1.116^{* * *} \\
(-3.10)\end{array}$ \\
\hline EDU & $\begin{array}{c}-38269.6^{*} \\
(-1.67)\end{array}$ & $\begin{array}{c}21196.6 \\
(0.88)\end{array}$ & $\begin{array}{c}-3898.3 \\
(-0.23)\end{array}$ & $\begin{array}{c}-2329.1 \\
(-0.14)\end{array}$ \\
\hline EXP & $\begin{array}{c}0.000718 \\
(0.00)\end{array}$ & $\begin{array}{c}0.856^{* * *} \\
(5.14)\end{array}$ & $\begin{array}{l}1.247 \\
(1.50)\end{array}$ & $\begin{array}{l}-0.167 \\
(-0.69)\end{array}$ \\
\hline URB & $\begin{array}{c}-9044.3 \\
(-0.17)\end{array}$ & $\begin{array}{c}-189510.4^{* *} \\
(-2.48)\end{array}$ & $\begin{array}{c}-153404.9^{* * *} \\
(-3.75)\end{array}$ & $\begin{array}{c}-116024.4 \\
(-1.29)\end{array}$ \\
\hline LOE & $\begin{array}{c}42972.9^{* *} \\
(2.49)\end{array}$ & $\begin{array}{c}-15819.6 \\
(-0.72)\end{array}$ & $\begin{array}{c}-16222.9 \\
(-1.46)\end{array}$ & $\begin{array}{c}19248.0 \\
(1.57)\end{array}$ \\
\hline POE & $\begin{array}{c}6641.1 \\
(1.06)\end{array}$ & $\begin{array}{c}-8736.0 \\
(-0.88)\end{array}$ & $\begin{array}{c}-31378.3^{* * *} \\
(-3.24)\end{array}$ & $\begin{array}{c}-1862.9 \\
(-0.37)\end{array}$ \\
\hline LIC & $\begin{array}{l}6.317 \\
(0.59)\end{array}$ & $\begin{array}{l}-26.42^{*} \\
(-1.87)\end{array}$ & $\begin{array}{l}-25.83 \\
(-1.59)\end{array}$ & $\begin{array}{l}-3.893 \\
(-0.30)\end{array}$ \\
\hline $\mathrm{S} \& \mathrm{~T}$ & $\begin{array}{c}0.0120 \\
(0.44)\end{array}$ & $\begin{array}{c}0.00690 \\
(0.26)\end{array}$ & $\begin{array}{c}-0.0205 \\
(-0.15)\end{array}$ & $\begin{array}{c}-0.0213 \\
(-0.25)\end{array}$ \\
\hline UER & $\begin{array}{c}14300.2^{* * *} \\
(3.73)\end{array}$ & $\begin{array}{c}2459.9 \\
(0.93)\end{array}$ & $\begin{array}{c}-6306.7^{* * * *} \\
(-2.71)\end{array}$ & $\begin{array}{c}3083.6 \\
(1.07) \\
\end{array}$ \\
\hline \multicolumn{5}{|c|}{ Total effect } \\
\hline RES & $\begin{array}{c}-24800.2 \\
(-0.29)\end{array}$ & $\begin{array}{c}-175349.7^{* * *} \\
(-3.19)\end{array}$ & $\begin{array}{c}551347.2^{*} \\
(1.70)\end{array}$ & $\begin{array}{c}-42533.7 \\
(-0.38)\end{array}$ \\
\hline PAR & $\begin{array}{c}1260417.8^{* * *} \\
(3.16)\end{array}$ & $\begin{array}{c}-169319.6 \\
(-0.58)\end{array}$ & $\begin{array}{c}210056.0 \\
(0.43)\end{array}$ & $\begin{array}{c}-386579.8 \\
(-0.86)\end{array}$ \\
\hline BAN & $\begin{array}{c}-18165.4^{* * *} \\
(-3.33)\end{array}$ & $\begin{array}{c}-1281.2 \\
(-0.34)\end{array}$ & $\begin{array}{c}-17232.9 \\
(-0.75)\end{array}$ & $\begin{array}{c}2855.1 \\
(0.37)\end{array}$ \\
\hline SEC & $\begin{array}{l}249.9 \\
(0.94)\end{array}$ & $\begin{array}{l}222.1 \\
(1.38)\end{array}$ & $\begin{array}{l}453.4 \\
(0.15)\end{array}$ & $\begin{array}{l}84.37 \\
(0.19)\end{array}$ \\
\hline INS & $\begin{array}{l}990.7 \\
(1.35)\end{array}$ & $\begin{array}{l}534.1 \\
(0.51)\end{array}$ & $\begin{array}{l}985.1 \\
(0.52)\end{array}$ & $\begin{array}{c}-1314.9 \\
(-0.18)\end{array}$ \\
\hline
\end{tabular}




\begin{tabular}{ccccc}
\hline \multirow{2}{*}{ INV } & 0.199 & -0.156 & $0.605^{* * *}$ & -0.666 \\
& $(0.95)$ & $(-0.70)$ & $(4.84)$ & $(-1.56)$ \\
EDU & $-42643.7^{*}$ & 23429.5 & -19906.9 & -9406.2 \\
& $(-1.75)$ & $(0.84)$ & $(-0.93)$ & $(-0.48)$ \\
EXP & 0.193 & $0.823^{* * *}$ & -0.114 & $(-0.41)$ \\
& $(0.98)$ & $(5.00)$ & $(0.61)$ & -70772.5 \\
URB & -74712.4 & $-393857.7^{* * *}$ & $-119682.3^{* * *}$ & $(-0.68)$ \\
& $(-1.53)$ & $(-4.72)$ & $(-3.14)$ & $30133.2^{* * *}$ \\
LOE & $54839.4^{* * *}$ & -19236.2 & 3292.6 & $(2.03)$ \\
& $(2.94)$ & $(-0.77)$ & $(0.24)$ & -2557.1 \\
POE & 5337.3 & $-21413.7^{* *}$ & $-38629.2^{* * *}$ & $(-0.49)$ \\
& $(0.85)$ & $(-2.09)$ & $(-3.44)$ & -4.017 \\
LIC & 9.400 & $-27.28^{*}$ & -4.370 & $(-0.29)$ \\
& $(0.83)$ & $(-1.78)$ & $(-0.25)$ & 0.133 \\
S\&T & $0.0469^{*}$ & 0.00890 & -0.265 & $(1.43)$ \\
& $(1.69)$ & $(0.31)$ & $(-1.61)$ & 4092.2 \\
UER & $15811.5^{* * *}$ & $6656.7^{* *}$ & $-4847.8^{* *}$ & $(1.34)$ \\
\hline Observed quantity & $(3.93)$ & $(2.22)$ & $(-2.02)$ & 100 \\
\hline
\end{tabular}

Note. $* * *, * *, *$ denotes significant at $1 \%, 5 \%, 10 \%$ significance level, respectively.

The test results of the cumulative effect in Table 6 show that the scale of local financial resources at the national level can promote the development of the local regional economy at a significant level of $10 \%$, while the scale of financial resources in the surrounding areas does not significantly affect the development of the local regional economy. Local financial resources can have a positive impact on local regional economic development at a $10 \%$ significance level, but the indirect effects and total effects are not significant. The scale of financial practitioners can promote local regional economic development at a level of $1 \%$, and the scale of financial practitioners in the surrounding areas can promote local economic development at a level of $1 \%$. The size of the local financial practitioners can have a positive impact on the local regional economic development at a significant level of $1 \%$, and can also have a positive impact on the economic development of the surrounding region at a level of 5\% significance, and is significant at $1 \%$. The sexual level has a positive impact on the economic development of the local and surrounding areas. The banking industry's location entropy hindered the local regional economic development at a significant level of $1 \%$. The banking sector location entropy in the surrounding areas also hindered the local regional economic development at the $1 \%$ significance level. The local banking industry location entropy can have a negative impact on the local regional economic development at a $1 \%$ significance level, and can also have a negative impact on the economic development of the surrounding area at a $1 \%$ significance level, and can be at $1 \%$ The level of significance has a negative impact on the local regional economy and the economic development of the surrounding areas. The location entropy of the securities industry has not had a significant impact on regional economic development from beginning to end, so the discussion was abandoned. The insurance industry location entropy promotes the local regional economic development at a significant level of $1 \%$. The banking industry location entropy in the surrounding areas cannot affect the local regional economic development. The local insurance industry location entropy can have a negative impact on local economic development at a $1 \%$ significance level, but the indirect and total effects are not significant. In terms of control variables, the per capita social fixed asset investment, per capita expenditure, localized economy, local fiscal transportation expenditure, domestic patent application authorization and urban registered unemployment rate can significantly promote local regional economic development to varying degrees. The urbanization rate will hinder the development of the local regional economy at a level of $1 \%$. The localized economy and urban registered unemployment rate in the surrounding areas can promote regional economic development in the region at a level of $1 \%$. The average educational level in the surrounding areas will hinder the region at a level of $10 \%$. economic development. The per capita social fixed asset investment, per capita expenditure, localized economy, local fiscal transportation expenditure, domestic patent application authorization and urban registered unemployment rate of local area will significantly promote local economic development in different regions, while the urbanization rate will hinder regional economic development in the region at a level of $1 \%$. The localized economy and the registered urban unemployment rate will significantly promote the regional economic development of the surrounding areas in different degrees, while the average education level of the region will hinder the regional economic development of the surrounding areas at the significance level of 
$10 \%$. The localized economy, the number of domestic patent application authorization and the urban registered unemployment rate will significantly promote the regional economic development of the region and the surrounding areas in different degrees, while the average education level will hinder the regional economic development of the region and the surrounding areas at the significance level of $10 \%$.

For the eastern region, the scale of financial resources in the region has hindered the development of the local regional economy at a significant level of $10 \%$, and the scale of financial resources in the surrounding areas has hindered the development of the local regional economy at a significant level of $1 \%$. The scale of financial resources cannot significantly affect the economic development of the local region, and the scale of local financial resources can have a negative impact on the economic development of local and surrounding regions at a level of $1 \%$. The size of the financial practitioners in the region cannot significantly affect the economic development of the local region, and the size of the financial practitioners in the surrounding areas cannot significantly affect the economic development of the local region. Moreover, there is no significant indirect effect and total effect. The regional banking entropy in the region has hindered the development of the local regional economy at a significant level of $1 \%$. The regional banking entropy in the region has promoted the regional economic development in the surrounding areas at a significant level of $10 \%$, but there is no significant Total effect. The location entropy of the banking sector in the surrounding areas cannot significantly affect the economic development of the local region. The location entropy of the insurance industry in the region cannot significantly affect the economic development of the local region. The location entropy of the insurance industry in the surrounding areas cannot significantly affect the economic development of the local region. There is also no significant direct, indirect and total effects in the insurance industry location entropy. In terms of control variables, the per capita social fixed asset investment and the registered urban unemployment rate in the region promoted the development of the local regional economy at the significance level of $1 \%$, while the urbanization rate and baud externalities hindered the development of the local regional economy at the significance level of $1 \%$. The per capita expenditure in the surrounding areas promoted the development of local regional economy at the significance level of $1 \%$, and the per capita fixed asset investment, urbanization rate and local financial transportation expenditure in the surrounding areas significantly promoted the regional economic development in the surrounding areas to different degrees. Per capita social fixed asset investment and registered urban unemployment rate promote the development of local regional economy at the significance level of $1 \%$, while urbanization rate and baud externality hinder the development of local regional economy at the significance level of $1 \%$. Per capita expenditure promoted the development of regional economy in surrounding areas at the significance level of $1 \%$. Per capita social fixed asset investment, urbanization rate and local financial transportation expenditure significantly hindered the development of regional economy in surrounding areas to different degrees. Per capita expenditure and registered urban unemployment rate significantly promote the regional economic development of the region and surrounding areas in different degrees, while urbanization rate, baud externality and local financial transportation expenditure significantly hinder the regional economic development of the region and surrounding areas in different degrees.

For the central region, the scale of financial resources in the region promoted the development of local regional economy at the significance level of 5\%, while the scale of financial resources in surrounding regions had no significant impact on the development of local regional economy. The scale of financial resources promotes the development of local regional economy at the significance level of $1 \%$, while the scale of financial resources has no significant impact on the development of regional economy in surrounding areas. The scale of financial resources promotes the development of regional economy in the region and surrounding areas at the significance level of $10 \%$. The size of the financial practitioners in the region has no significant impact on the development of the local regional economy, and the size of the financial practitioners in the surrounding areas has no significant impact on the development of the local regional economy. The size of financial practitioners does not have significant direct, indirect and total effects. The regional banking location entropy promotes the development of regional economy in the region and surrounding areas at the significance level of $10 \%$, while the regional banking location entropy has no significant influence on the development of local regional economy. The location entropy of the banking industry promotes the development of the local regional economy at the significance level of $1 \%$, and hinders the development of the regional economy of the surrounding areas at the significance level of 5\%. The location entropy of the banking industry has no significant influence on the development of the regional economy of the region and the surrounding areas. The location entropy of the insurance industry in the region and surrounding areas has no significant impact on the development of the local regional economy. The insurance industry location entropy hinders the development of the local regional economy at a significant level of 5\%. The insurance industry location entropy does not have significant indirect effects and total effects. In terms of control variables, the per capita social fixed asset investment, localized 
economy and local fiscal transportation expenditure in the region promoted the development of the local regional economy at a significant level of $1 \%$. The average educational level in the region, Porter's external Sexual and domestic patent application authorizations significantly hinder regional economic development in different degrees. The per capita social fixed asset investment in the surrounding area promoted the development of the local regional economy at a level of $1 \%$. The urbanization rate, porter externalities and urban registered unemployment rate in the surrounding areas significantly hindered regional economic development. Per capita social investment in fixed assets promoted regional economic development in the surrounding areas at a level of $10 \%$. The urbanization rate, porter externalities and urban registered unemployment rate hindered regional economic development in the surrounding areas at a significant level of $1 \%$. Per capita social investment in fixed assets promoted regional economic development in the region and surrounding areas at a significant level of $1 \%$. Urbanization rate, porter externality and urban registered unemployment rate significantly hindered regional economic development in the region and surrounding areas in different degrees.

For the western region, the scale of financial resources in the region has no significant impact on the development of the local regional economy, and the scale of financial resources in the surrounding regions has no significant impact on the development of the local regional economy. The scale of financial resources does not have significant direct, indirect and total effects. The size of the financial practitioners in the region has no significant impact on the development of the local regional economy and the size of the financial practitioners in the surrounding areas has no significant impact on the development of the local regional economy. The size of financial practitioners does not have significant direct, indirect and total effects. The location entropy of the banking industry in this region has no significant impact on the development of the local regional economy. The location entropy of the banking industry in the surrounding areas has no significant impact on the regional economic development of the region. The banking industry location entropy has no significant impact on the development of the local regional economy. There is no significant direct, indirect and total effects in the banking industry location entropy. The location entropy of the insurance industry in the region and surrounding areas has no significant impact on the development of the local regional economy. The insurance industry location entropy does not have significant direct, indirect and total effects. In terms of control variables, the per capita social fixed asset investment, localized economy, domestic patent application authorization and urban registered unemployment rate in the region have significantly promoted regional economic development in the region. The localized economy in the surrounding areas promoted the regional economic development in the region at a level of $10 \%$. The per capita social investment in fixed assets in the surrounding areas hindered the regional economic development in the region at a significant level of $1 \%$.

\section{Conclusion and Policy Implications}

Using the spatial Durbin model (SDM) in spatial measurement to analyze the financial agglomeration degree of China's provinces, municipalities and autonomous regions and the eastern, central and western regions from 2006 to 2015, and the impact of financial agglomeration on China's regional economic growth, this paper finds that many elements of financial agglomeration has a significant impact on the GDP development of a region. The specific research on the correlation between China's financial agglomerations related factors and the development of regional economics has been carried out. It is found that it also has a strong impetus to the economic development of neighboring regions, and there is a significant spatial spillover effect.

In the future development, China should insist on promoting and devoting itself to the healthy development of the financial industry. China's prudent macroeconomic policies, as well as supporting monetary and fiscal policies, have contributed greatly to China's economic recovery. Financial regulation is an important responsibility of national and local governments. Government financial supervision departments can establish various cooperative relationships with the financial industry in the process of financial management. Only under the macro-control of the government, moderately benign market competition can promote the healthy development of the financial industry, thus promoting the rapid development of regional economy.

Strengthening regional financial ties. To strengthen the level of financial industry development in the central and western regions, there is a big gap in scale and economic efficiency compared with that in the eastern region of China. As can be seen from the empirical results, many factors of the financial industry have a positive overall effect on the regional GDP per capita. Therefore, when developing regional economy, the central and western regions need to continuously strengthen the development of financial industry. The significant spatial spillover effect found in the empirical results shows that it is effective to increase the development of the financial industry in the central and western regions. Promoting the development of the financial industry in the central and western regions can not only effectively absorb the excess capacity in the construction of related industrial facilities in the eastern region, but also strengthen the eastern region. The regional economic and trade exchanges, 
in response to the national "Belt and Road" call to connect neighboring countries, can also provide a channel for the digestion and export of some excess capacity in the western region, and promote the level of regional economic exchanges. Compared with the central and western regions, the eastern region has a high degree of financial agglomeration. Through empirical results, it is found that the securities industry has no significant impact on economic development, and the insurance industry has the most significant effect on economic development. Therefore, the mutual coordination and common development between different regions and different financial industries is very important. It is necessary to constantly seek a balance between financial development and regional development in order to achieve mutual promotion and coordination.

\section{References}

Bai, C., Ma, H., \& Pan, W. (2012). Spatial spillover and regional economic growth in China. China Economic Review, (23), 982-990. https://doi.org/10.1016/j.chieco.2012.04.016

Li, H., \& Wang, Y. (2014). Financial Agglomeration, Spatial Spillover, and Economic Growth of Cities Empirical Evidence from Spatial Durbin Model of 286 Cities of China (in Chinese). Financial Markets, (2), 89-96.

Zhou, J., Chen, M., \& Wang, L. (2014). Financial Agglomeration of Shaanxi Province - Based on Location Entropy (in Chinese). Statistics \& Decision, (24), 176-179. https://doi.org/10.13546/j.cnki.tjyjc.2014.24.052

Wang, Y., Guo, X., \& Gan, C. (2015). Financial Agglomeration and International Finance Center Construction Research: A Perspective of DSGE and News Shock. China Economic Quarterly, (1), 331-350. https://doi.org/10.13821/j.cnki.ceq.2015.01.017

Li, Y., Li, H., \& Shi, X. (2016). The Spatial Spillover Effects and Influence Pathway of Financial Agglomeration in Beijing-Tianjin-Hebei Region. Finance Forum, (2), 20-29. https://doi.org/10.16529/j.cnki.11-4613/f.2016.11.003

Sun, Z., \& Wang, Y. (2017). The Study of Spatial Spillover Effects of Financial Agglomeration on Regional Economic Growth: Based on the Data of Five Northwestern Provinces. Journal of Audit \& Economics, (2), $108-118$.

\section{Copyrights}

Copyright for this article is retained by the author(s), with first publication rights granted to the journal.

This is an open-access article distributed under the terms and conditions of the Creative Commons Attribution license (http://creativecommons.org/licenses/by/4.0/). 